\title{
PENERAPAN PENDEKATAN PEMBELAJARAN INQUIRI UNTUK MENINGKATKAN HASIL BELAJAR SISWA KELAS XII AKUNTANSI-2 MATA PELAJARAN PENDIDIKAN AGAMA ISLAM MATERI PERNIKAHAN DALAM ISLAM PADA SMK NEGERI 1 SIGLI
}

\author{
Meutia \\ SMK Negeri 1 Sigli \\ Email : meutia1977@gmail.com
}

\begin{abstract}
ABSTRAK
Rendahnya hasil belajar Pendidikan Agama Islam merupakan permasalahan besar bagi seorang siswa karena di dalam pendidikan agamalah awal terbentuknya akhlak seorang anak. Permasalahan ini dapat saja disebabkan karena pengunaan metode belajar yang kurang tepat sehingga peserta didik sulit memahami materi yang ada. Penelitian ini dilakukan di SMK Negeri 1 Sigli selama tiga bulan sejak bulan Januari sampai Maret 2021 bertujuan untuk meningkatkan hasil belajar siswa kelas XII Akuntansi-2 mata pelajaran pendidikan agama Islam materi pernikahan dalam Islam melalui penerapan pendekatan pembelajaran inquiri pada SMK Negeri 1 Sigli. Metode penelitian yang digunakan adalah penelitian tindakan kelas (PTK) yang terdiri atas 2 siklus. Subyek penelitian adalah siswa-siswi Kelas XII Akuntansi-2 SMK Negeri 1 Sigli tahun pelajaran 2020/2021 sebanyak 31 siswa. Analisis data menggunakan teknik analisis deskriptif komparatif dengan membandingkan kondisi awal dengan hasil-hasil yang dicapai pada setiap siklus, dan analisis deskriptif kualitatif hasil observasi dengan membandingkan hasil observasi dan refleksi pada siklus I dan siklus 2. Hasil penelitian diperoleh pada siklus I dengan persentase ketuntasan sebesar 67,7\% nilai rata-rata kelas sebesar 70,6 dan meningkat pada hasil tes siklus II sebesar 96,8\% dengan nilai rata-rata kelas 81,9. Pada kedua siklus ini terjadi perubahan aktifitas dan perolehan nilai yang signifikan bila dibandingkan dengan pra siklus dengan ketuntasan belajar yang hanya mencapai $38,7 \%$ dan nilai rata-rata adalah 60 . Dapat disimpulkan melalui penerapan pendekatan pembelajaran inquiri dapat meningkatkan hasil belajar siswa kelas XII Akuntansi-2 mata pelajaran pendidikan agama Islam materi pernikahan dalam Islam pada SMK Negeri 1 Sigli.
\end{abstract}

Kata Kunci : Pendekatan Pembelajaran Inquiri, Hasil Belajar, Pernikahan Dalam Islam

\section{PENDAHULUAN}

Pendidikan agama Islam adalah pendidikan yang ditujukan untuk dapat menserasikan, menselaraskan dan menyeimbangkan antara iman, Islam, dan ihsan. Kiranya tidak asing lagi apabila mendengar guru-guru agama yang menyatakan keluhan-keluhan tentang pengajaran materi pendidikan agama, khususnya di sekolah-sekolah umum. Hal ini disebabkan karena adanya faktor ketakutan dari siswa itu sendiri yang menganggap materi pendidikan agama adalah materi yang paling menyulitkan untuk dipelajari. Ketika seorang guru memberikan materi pendidikan agama saat itu juga siswa merasa kurang berminat, kurang termotivasi untuk mempelajari atau untuk menerimanya. Akibatnya, dapat mengurangi keefektifan proses belajar mengajar.

Kenyataan bahwa Pendidikan Agama Islam merupakan salah satu mata pelajaran yang sulit bagi siswa SMK. Hal ini dialami oleh siswa SMK Negeri 1 Sigli dimana nilai Pendidikan Agama Islam umumnya rendah, hasil ulangan harian yang didapatkan siswa 
kelas XII Akuntansi-2 SMK Negeri 1 Sigli, rata-rata hasil ulangan harian Pendidikan Agama Islam nilainya sangat rendah. Dari jumlah siswa sebanyak 31 orang, hanya 12 orang siswa atau $38,7 \%$ yang memperoleh ketuntasan belajar. Sedangkan 19 orang atau $61,3 \%$ siswa memperoleh nilai di bawah KKM (Kriteria Ketuntasan Minimal).

Salah satu permasalahan yang mengakibatkan rendahnya hasil belajar Pendidikan Agama Islam adalah selama ini para siswa umumnya menerima pelajaran Pendidikan Agama Islam dengan metode ceramah dan diskusi tanpa dikenalkan dengan model pembelajaran yang interaktif.

Dalam penelitian tindakan kelas ini, peneliti mencoba mengetengahkan salah satu bentuk pembelajaran aktif, kreatif, efektif, dan menyenangkan. Dalam penyampaian pembelajaran ini peneliti menggunakan pendekatan pembelajaran inquiri.

Berdasarkan latar belakang di atas, penulis ingin meningkatkan nilai Pendidikan Agama Islam pada siswa kelas XII Akuntansi-2 SMK Negeri 1 Sigli melalui penelitian dengan judul "Penerapan Pendekatan Pembelajaran Inquiri Untuk Meningkatkan Hasil Belajar Siswa Kelas XII Akuntansi-2 Mata Pelajaran Pendidikan Agama Islam Materi Pernikahan Dalam Islam Pada SMK Negeri 1 Sigli”.

\section{KAJIAN KEPUSTAKAAN}

Hamalik (2008) mengemukakan bahwa "Belajar adalah suatu proses perubahan tingkah laku individu melalui interaksi dengan lingkungan". Selanjutnya Sanjaya (2008) berpendapat bahwa, "Belajar adalah sebagai proses perubahan tingkah laku akibat dari pengalaman dan latihan". Sedangkan hasil belajar merupakan sesuatu yang diperoleh dari dan sesudah kegiatan pembelajaran berlangsung. Hasil belajar ini dinyatakan dalam bentuk angka, huruf atau kata-kata baik, sedang dan kurang. Hasil belajar ini merupakan kemampuan aktual yang dapat diukur langsung melalui tes yang sesuai dengan tujuan pembelajaran.

Nasution (2005) mendefinisikan pembelajaran sebagai suatu aktivitas mengorganisasi atau mengatur lingkungan sebaik-baiknya dan menghubungkannya dengan anak didik sehingga terjadi proses belajar. Lingkungan dalam pengertian ini tidak hanya ruang belajar, tetapi juga meliputi guru, alat peraga, perpustakaan, laboratorium, dan sebagainya yang relevan dengan kegiatan belajar peserta didik. Sebagai suatu upaya yang dilakukan dengan sengaja oleh guru untuk menyampaikan ilmu pengetahuan, mengorganisasi dan menciptakan sistem lingkungan dengan berbagai metode sehingga peserta didik dapat melakukan kegiatan belajar secara efektif dan efisien serta dengan hasil optimal.

Pendekatan ilmiah yang dapat digunakan untuk memperoleh pengetahuan dapat dilakukan dengan cara menyelidikinya sendiri. Pendekatan dengan cara penyelidikan dalam bahasa inggris dikenal dengan nama "Inquiry". Inkuiri secara harfiah berarti pertanyaan, atau pemeriksaan, penyelidikan.

Gulo (2005) menyatakan bahwa
kemampuan yang diperlukan untuk
melaksanakan pembelajaran inkuiri adalah
sebagai berikut:
1) Orientasi

Orientasi merupakan langkah membina suasana atau iklim pembelajaran yang responsif. Guru merangsang dan mengajak peserta didik untuk berfikir memecahkan masalah. Beberapa hal yang dapat dilakukan dalam tahap orientasi adalah:

a) Menjelaskan topik, tujuan dan hasil belajar yang diharapkan akan dicapai peserta didik.

b) Menjelaskan pokok-pokok kegiatan untuk mencapai tujuan 
c) Menjelaskan pentingnya topik dan kegiatan belajar sebagai motivasi bagi peserta didik.

2) Merumuskan masalah

Perumusan masalah merupakan langkah membawa peserta didik pada suatu persoalan yang mengandung teka-teki. Tekateki yang menjadi persoalan dalam inkuiri harus mengandung konsep yang jelas dan pasti. Konsep-konsep dalam masalah adalah konsep-konsep yang sudah diketahui terlebih dulu oleh peserta didik.

3) Merumuskan hipotesis

Hipotesis adalah jawaban sementara dari suatu permasalahan yang sedang dikaji sehingga perlu diuji kebenarannya. Salah satu cara yang dapat dilakukan guru adalah dengan mengajukan pertanyaan yang dapat mendorong peserta didik untuk dapat merumuskan berbagai perkiraan kemungkinan jawaban dari suatu permasalahan.

4) Mengumpulkan data

Pengumpulan data adalah aktivitas menjaring informasi yang dibutuhkan untuk menguji hipotesis yang diajukan. Tugas guru dalam tahap ini adalah mengajukan pertanyaan yang dapat mendorong peserta didik untuk berfikir mencari informasi yang dibutuhkan.

5) Menguji hipotesis

Pengujian hipotesis adalah proses menentukan jawaban yang dianggap diterima sesuai dengan data atau informasi yang diperoleh berdasarkan pengumpulan data sehingga guru dapat mengembangkan kemampuan berfikir rasional peserta didik.

6) Merumuskan kesimpulan

Perumusan kesimpulan merupakan proses mendeskripsi kan temuan yang diperoleh berdasarkan hasil pengujian hipotesis

\section{METODE PENELITIAN}

Penelitian ini merupakan penelitian tindakan kelas. Penelitian dilaksanakan di SMK Negeri 1 Sigli di kelas XII Akuntansi2 pada pelajaran pendidikan agama Islam yang dilaksanakan selama 3 bulan yaitu pada bulan Januari s/d Maret 2021 Tahun Pelajaran 2020/2021. Subyek penelitian adalah siswa-siswi kelas XII Akuntansi-2 dengan jumlah siswa sebanyak 31 orang siswa.

Teknik pengumpulan data yang dilakukan adalah observasi dan tes. Alat pengumpulan data yang digunakan adalah: Lembar instrument aktifitas siswa dalam PBM, Lembar intrumen PBM guru dan 20 butir soal test. Analisis data yang digunakan adalah analisis deskriptif kualitatif.

Dalam penelitian PTK menggunakan dan mengembangkan siklus yang mengandung empat komponen yaitu: rencana tindakan (planning), (2) pelaksanaan (action), (3) observasi (observation), (4) refleksi (reflection).

\section{HASIL PEMBAHASAN}

Pada siklus I dan siklus 2 masingmasng terjadi dua kali pertemuan atau dua kali tatap muka.

Berdasarkan hasil pengamatan pada siklus I dan siklus II mengalami peningkatan hasil belajar dan juga aktivitas baik bagi guru maupun bagi siswa dalam kegiatan belajar mengajar dan mencapai ketuntasan. Hasil tes pada siklus I dengan persentase ketuntasan sebesar $67,7 \%$ nilai rata-rata kelas sebesar 70,6 dan hasil tes siklus II sebesar 96,8\% dengan nilai rata-rata kelas 81,9. Maka terlihat bahwa nilai siswa telah mencapai standar ketuntasan secara klasikal pada siklus II yaitu $\geq 85 \%$. Dengan demikian dapat disimpulkan terdapat peningkatan hasil belajar siswa kelas I materi pernikahan dalam Islam melalui pendekatan pembelajaran inquiri pada SMK Negeri 1 Sigli. Hal ini disebabkan adanya peningkatan keaktifan dan keterampilan siswa sehingga mengakibatkan efek yang positif terhadap pemahaman siswa dalam mempelajari materi ajar. Hasil tes pada siklus I dan II berbeda dengan hasil tes pra siklus dengan perolehan nilai rata-rata kelas adalah 63,1 dan ketuntasan siswa yang dicapai hanya $38,7 \%$. 
Untuk lebih jelasnya perkembangan aktivitas siswa, aktivitas guru dan nilai siswa pada masing-masing siklus dan pertemuan dapat dilihat pada diagram berikut ini:

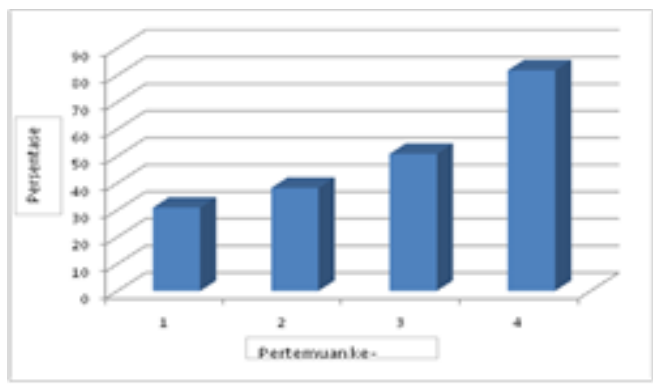

Gambar 4.1 Diagram Aktivitas Siswa

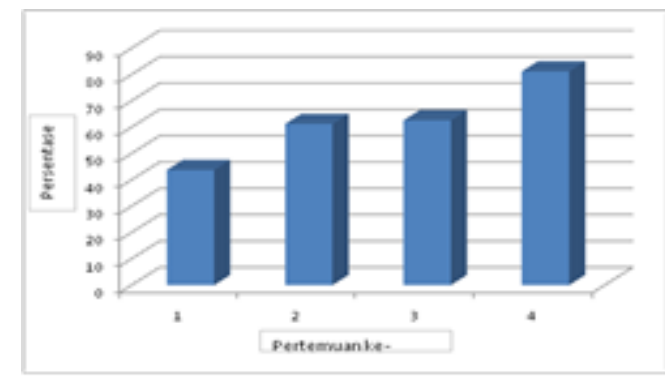

Gambar 4.2 Diagram Aktivitas Guru

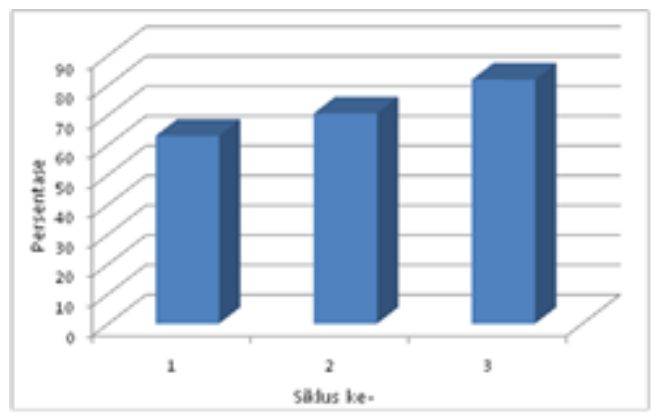

Gambar 4.3 Daftar Nilai Siswa

\section{KESIMPULAN}

Berdasarkan hasil penelitian ini dapat disimpulkan bahwa dengan penerapan pendekatan pembelajaran inquiri dapat meningkatkan hasil belajar siswa kelas XII Akuntansi-2 mata pelajaran pendidikan agama Islam materi pernikahan dalam Islam pada SMK Negeri 1 Sigli. Peningkatan hasil belajar siswa tersebut terlihat dalam hal meningkatnya nilai rata-rata, persentase ketuntasan siswa dan juga suasana belajar siswa yang berbeda dari suasana belajar sebelum dilakukan tindakan.
1. Hasil perolehan pada siklus I dengan persentase ketuntasan sebesar $67,7 \%$ nilai rata-rata kelas sebesar 70,6 dan meningkat pada hasil tes siklus II sebesar $96,8 \%$ dengan nilai rata-rata kelas 81,9. Pada kedua siklus ini terjadi perubahan aktifitas dan perolehan nilai yang signifikan bila dibandingkan dengan pra siklus dengan ketuntasan belajar yang hanya mencapai $38,7 \%$ dan nilai rata-rata adalah 60 .

2. Adapun hasil pengamatan pada proses belajar mengajar menunjukkan aktivitas siswa lebih meningkat selama proses pembelajaran berlangsung, baik pada siklus I maupun pada siklus II, di bandingkan dengan suasana belajar siswa yang pasif dan terkesan kaku sebelum dilakukannya tindakan kelas. Perolehan persentase siswa yang aktif pada akhir siklus I adalah $45 \%$ dan pada akhir siklus II adalah 61,43\%. Aktivitas guru juga meningkat pada siklus I dan siklus II dalam hal penerapan pendekatan pembelajaran inquiri dengan perolehan persentase skor adalah $41,43 \%$ dengan kategori cukup menjadi $82,86 \%$ pada siklus II dengan kategori baik.

Merujuk dari hasil penelitian yang diperoleh, penulis dapat menyarankan antara lain: pertama Sebaiknya pembelajaran inquiri digunakan oleh pendidik dalam proses belajar mengajar di kelas karena pembelajaran inquiri dapat meningkatkan hasil belajar peserta didik pada materi pernikahan dalam Islam. Kedua Pemahaman terhadap pembelajaran inquiri perlu diberikan kepada peserta didik agar mampu menganalisis masalah yang dihadapi tentang mata pelajaran pendidikan agama Islam dan memotivasi peserta didik agar berfikir kritis dan logis.

\section{DAFTAR PUSTAKA}

Anas Sudijono. 2005. Pengantar Evaluasi Pendidikan. Jakarta : PT. Raja Grafindo Persada. 
Jurnal Sosial Humaniora Sigli (JSH)

p ISSN : 2615-3688

$e$ ISSN : 2716-0270

http://journal.unigha.ac.id/index.php/JSH

Aqib, Zainal, 2009. Penelitian Tindakan Kelas untuk Guru. Bandung: Yrama Widya

Hamalik, Oemar. 2008. Kurikulum dan Pembelajaran. Jakarta : Bumi Aksara.

Irwan Nasution dan Syafaruddin. 2005. Manajemen Pembelajaran. Jakarta: Quantum Teaching

Sarlito Wirawan, 2009. Psikologi Sosial. Jakarta : Salemba Humanika.
Slameto. 2003. Belajar dan Faktor-faktor yang Mempengaruhinya. Bandung: PT. Rineka Cipta.

Sudjana, Nana. 2000. Cara Belajar Siswa Aktif dalam Proses Belajar Mengajar. Bandung: Sinar Baru Algesindo.

W. Gulo. 2005. Strategi Belajar Mengajar Jakarta : Grasindo.

Wina Sanjaya. 2008. Belajar dan FaktorFaktor Yang Mempengaruhinya. Rineka Cipta; Jakarta. 